\title{
Poor Governance and Civil War in Syria
}

Mahdi Karimi*-Sayed Masoud Mousavi Shafaee ${ }^{* *}$

\begin{abstract}
Civil war in Syria started in 2011 provide an important and rich area of investigation into the study of civil war. The present study is intended to concentrate on the cause of Syrian civil war. The main focus of the paper is on the investigation of why and how civil war in Syria was triggered. Despite the various ways in which Syrian civil war can be addressed, the paper benefited from good/ poor governance theoretical framework to investigate the cause of the civil war. The findings support the theoretical argument that poor governance has led to civil war in Syria. Governance indicators show lack of free and fair elections, low level of rule of law, high level of corruption, lack of voice and accountability, exclusion of different interest groups, inequity and government ineffectiveness in Syria which have been resulted in lasting civil war.
\end{abstract}

Keywords: Civil War, Syria, Poor Governance, Exclusion, Lack of Accountability

* Dr., Tarbiat Moderes University, Political Geography, karimisoltan@modares.ac.ir

** Prof. Dr., Tarbiat Moderes University, International Relations, shafaee@modares.ac.ir 


\title{
Kötü Yönetim ve Suriye İç Savaşı
}

\author{
Mahdi Karimi*-Sayed Masoud Mousavi Shafaee**
}

\section{Öz}

2011 yılında Suriye'de başlamış olan iç savaş, iç savaş alanda yapılan çalışmalar için önemli ve zengin bir araştırma alanı sağlamıştır. Bu çalışma Suriye iç savaşının nedenine odaklanmıştır. Suriye'deki iç savaşın neden ve nasıl tetiklendiği bu çalışmanın ana konusunu oluşturmaktadır. Suriye iç savaşını ele almak için çeşitli kuram ve yöntemlere başvurulabilmesine rağmen, bu çalışmada iç savaşın nedenlerini araştırmak için "iyi/zayıf yönetişim kuramı" çerçevesinden yararlanılmıştır. Çalışmanın teorik tartışmasını oluşturan zayıf yönetişimin Suriye'de iç savaşa yol açtığı meselesi, elde edilen sonuçlarla desteklenmiş̧ir. Suriye'de sürmekte olan iç savaşla sonuçlanan yönetişim göstergeleri serbest ve adil seçimlerin olmaması, hukuk üstünlüğünün zayıf olması, yüksek düzeyde yolsuzluk, sessizlik ve hesap sorulmaması, farklı çıkar gruplarının dışlanması, eşitsizlik ve devletin etkisizliğini göstermektedir.

Anahtar Kelimeler: İç Savaş, Suriye, Zayıf Yönetim, Dışlanma, Hesap Verilebilirliğin Olmaması

* Dr., Tarbiat Moderes Üniversitesi, Siyasi Coğrafya, karimisoltan@modares.ac.ir

** Prof. Dr., Tarbiat Moderes Üniversitesi, Uluslararası İlişkiler, shafaee@modares.ac.ir 


\section{Introduction}

The nature of war has changed markedly in recent decades. While interstate wars have largely decreased, intrastate conflicts have dramatically increased. ${ }^{1}$ As Smith put it, the new paradigm is "war amongst the people," in where the communities divided by ethnicity, language, religion and geography. ${ }^{3}$ Despite this massive scale of human misery resulted from civil war, the academic community has not concentrated much attention on the problem of civil war. The urgency to prevent genocide, oppression, and terrorism has started a new wave of actions and inquiries, and has increasingly led to search for ways to prevent and resolve civil war.

In contrast with the Cold War era in which power concentration was one of its main characteristics, in the post-cold war era we are witnessing diffusion of power, creation of multipolar/nonpolar order which have caused international system to be fluctuated and transitional. In such a new era, ability and will of great powers for direct engagement in regional affairs has been decreased and consequently has provided regional/newly emerging powers with more space for playing active role in the regions. In this situation, regional powers are converted to new active actors and try to promote their power and influence in the regional context. This situation is resulted in "order- lack of order," "stability- instability," and "prosperity and collapse" in the regions. Where regional order is not established, the main part of regional powers potentialities is allocated to avert each other actions which pave the way for collapsing regional states and growth of terrorism and fundamentalism.

In such a context, situation in the Middle East is more complicated. From political and geopolitical perspective, the US is not intended to engage in the region directly. The following power vacuum is resulted in regional powers rivalries, and they neither have power resources to establish their desired single hegemony, nor needed capacity for regional cooperation to create a corporative regional order. This situation along with poor gover-

1 Cortright David, Peace: A History of Movements and Ideas, (Cambridge University Press, 2008), 4.

2 Smith Rupert, The Utility of Force: The Art of War in the Modern World, (USA: Vintage Books, 2008), 3.

3 Harbom Lotta, Stina Högbladh and Peter Wallensteen, "Armed Conflict and Peace Agreements," Journal of Peace Research 43, no. 5 (2006), 617-31. 
nance have paved the way for growth of fundamentalism, terrorism and collapse of weak states.

Syria where of the $18 \%$ reported armed conflicts in 2013 were in this region, ${ }^{4}$ provides an important and rich area of investigation into the study of civil war. Some have tried to address the causes of political instabilities in general, and in the Middle East, in particular. They focus on the different factors ranging from foreign intervention ${ }^{5}$ to economic factors ${ }^{6,7}$ as the motives of the civil war. Some believes that the rise in terrorist activities and civil wars coexisted with the US invasion of Iraq created large power vacuums in the country paying the way for violence. But we believe this is a trigger factor allowing different factions to surface, and it is not the root cause of the civil war in the region. As Andrew Heywood ${ }^{8}$ put it the political instability in the Middle East can be traced back to the collapse of the Ottoman Empire in 1918. This led to the establishment of UK and French 'mandates' over Syria, Lebanon, Palestine and Iraq. This on the one hand, bred a sense of humiliation and disgrace, and also resulted in political borders which reflected the interests of Western powers and showed no regard for the facts of history, culture and ethnicity, and from the other hand resulted in the installation of authoritarian, and poor governments all around the region. This paper complements theoretical and empirical literature by developing a systematic investigation of the role of poor governance as a determinant cause of civil war in Syria. Regarding this factor, the article illuminates how poor governance has led to the civil war in Syria.

The paper is intended to investigate why and how civil war in Syria was triggered. In doing so, after reviewing the existing civil war theories, we further a theoretical framework to study the civil war in Syria, which is the paper innovation. In order to investigate the why roots of civil war in Syria we use governance characteristics. Also, we consider regional effects and

4 Armed Conflict Report, Project Ploughshares, ploughshares.ca/wp-content/.../2014ARMED-CONFLICT-REPORT.pdf.

5 Albornoz Facundo and Esther Hauk, "Civil War and U.S. Foreign Influence," Journal of Development Economics 110 (2014): 64-78.

6 Sambanis Nicholas, "Using Case Studies to Refine and Expand the Theory of Civil War," Understanding civil war 1 (2005): 303-34.

7 Djankov Simeon and Marta Reynal-Querol, "Poverty and Civil War: Revisiting the Evidence," The Review of Economics and Statistics 92, no. 4 (2010): 1035-41.

8 Heywood Andrew, Global Politics (Palgrave Macmillan, 2011), 47. 
international relations situation to understand when and how the civil war was triggered. In recent research, governance is assumed as a determinant cause, and regional effects and the nature of international system as effective factors.

\section{Civil War Theories}

Klem and Frerks ${ }^{9}$ argue that three major schools of thought can be found out on the root causes of violent conflict: the cultural school, the economic school, and the political regime school. The cultural school search the root causes of civil in cultural difference. Ethnic nationalism is often seen as the main source of group consolidation and intergroup war. ${ }^{10}$ In this view, ethnic groups rebel because they feel exclusion arising from discrimination by ethnic majorities. ${ }^{11}$ Also, "modernist" theories highlight this point of view and emphasize that ethnic conflicts arises when these groups are socially and politically excluded from economic modernization. ${ }^{12}$

This school of thought is poor to address all of the civil wars, and have some deficiencies. Ethnic, cultural and religious fractionalization cannot be as the cause of civil war, in itself. A reason that there are many states around the world with different ethnic, cultural and religious groups, but have not had experienced civil war. These cleavages should be inconsistent with other factors (i.e. low income, exclusiveness, poor governance) to act as a driving force in civil war.

The economic school describes the civil war based on economic factors like rebels seeking economic gain and low income. The first one presented by Trygve Haavelmo is called competition for resources. ${ }^{13}$ This theory

9 Klem M, and G Frerks, "How Local Governments Contribute to Peace-Building." Musch et al. (2006) City Diplomacy. The Role of Local Governments in Conflict Prevention, Peace-building, Post-Conflict Reconstruction. The Hague: VNG International (2008): 47-74.

10 Fearon James D, "Ethnic Mobilization and Ethnic Violence," The Oxford Handbook of Political Economy (2006): 852-68.

11 Horowitz Donald L, Ethnic Groups in Conflict, (Univ of California Press, 1985), 188.

12 Gellner Ernest and John Breuilly, Nations and Nationalism, (Cornell University Press, 2008), 1 .

13 Haavelmo TT, A Study in the Theory of Economic Evolution, (Netherlands: North Holland Publishing Company, 1954). 
considers two rivalry parties, a rebel group and a government that compete for resources. The absence of resources in this situation means that there is a smaller pie to fight over ${ }^{14}$ which makes the war sever and more violent. The second, low-income is another economic factor which has had prominent place in civil war theories. Collier et al. ${ }^{15}$ showed that low-income countries are prone to risk of civil war 15 times higher than the OECD countries. Some believe that many contemporary civil wars also are taken place in 'weak' states ${ }^{16}$ and poverty attributes to civil war. The correlation between low per capita income and higher inclination to civil war is one of the strongest empirical relationships in the civil war studies. ${ }^{17}$

The economic theories of civil war are under question from two points of view: firstly, they have linear approach to the civil war, and do not present a theoretical frame to understand how and when the civil war is occurred. An understanding of how and when the civil war is occurred helps us to identify the states which are prone to the civil war. Secondly, these theories do not present a solution to settle the ongoing and future possible civil wars.

The political regime school searches the cause of violent conflict in the lack of democracy and mechanisms to peacefully address the problems existed between different rival groups. In this view, a functioning, pluralistic, and mature democracy is an essential component of perpetual peace, regarding that a freely and just competitive electoral process provide an alternative to use violence to express grievances or achieve political goals. ${ }^{18}$ Thus, democracy is a powerful form of nonviolent dispute settlement. ${ }^{19}$ Democracy can provide a system in that marginalized groups can voice their opinions. The equity that a deep democracy can provide would be

14 Blattman Christopher, and Edward Miguel, "Civil War," Journal of Economic Literature (2010): 3-57.

15 Collier Paul, Breaking the Conflict Trap: Civil War and Development Policy. (World Bank Publications, 2003), 5.

16 Collier Paul, Understanding Civil War: Africa. Vol. 1: (World Bank Publications, 2005), p.IX.

17 Blattman Christopher and Edward Miguel, "Civil War," 3-57.

18 Evans Idris, Jessica Lane, Megan Turner and Jessica Pealer, "A Conceptual Model of Peace Building and Democracy Building: Integrating the Fields," 2013, 1.

19 Kinsella David and D Rousseau, "Democracy and Conflict Resolution," Handbook on Conflict Resolution (2009): 475-92. 
solution to prevent particular ethnic, religious, or social groups' inclusion, which consequently supports peace by alleviating the potential resentment and fear that minority groups may have toward the majority. ${ }^{20}$

Although the political regime school is rich to address the root causes of civil war, but it has some limitations. First, international relations scholars have questioned the empirical validity of this claim that democracies do not often experience civil conflict. Second, democracies can settle the peace provided that it has the following characteristics: first) it should guarantee the minority groups' rights and wills; second) being accountable and transparent; third) it should guarantee the mediation of the different interests in society to reach a broad consensus in society; fourth) providing processes and institutions which meet the needs of society; fifth) providing a system that grantee the rule of law. To some extent these characteristics are correspond with good governance characteristics.

Existing civil war theories are poor to address why, how and when the civil war is occurred. These three schools would be essentially seen complementary, and only a combination of social-cultural, political and economic reasons can explain the root causes of civil war. Governance has the potential of combination of the three schools, and can provide us with a comprehensive theoretical framework. Regarding that governance refers to various ways through which social life is coordinated, good governance can underpin peace.

\section{Governance: A Framework to Study Civil War}

There is a shift from government to governance, ${ }^{21}$ and the cause of the shift lies in the benefits of good governance in facing with the political, social and economic challenges. The World Bank ${ }^{22}$ and other multilateral development funds focus on transparency and accountability, regulatory reform, and public-sector skills and leadership -namely on economic institutions

20 Evans Idris, Jessica Lane, Megan Turner and Jessica Pealer, "A Conceptual Model of Peace building and Democracy Building: Integrating the Fields," School of International Service, (American University, 2013), 8.

21 Heywood Andrew, Global Politics, 121.

22 World Bank. "Worldwide Governance Indicators." 2014a. http://databank.worldbank. org/data/reports.aspx?Report_Name=WGI-Table\&Id=ceea4d8b. 
and public-sector management- as good governance indicators. Other organizations, like the United Nations highlight political aspects of governance including democracy and human rights which avoided by the World Bank. The European Union defines governance by the following indicators: openness, participation, accountability, effectiveness and coherence. ${ }^{23}$ Also, United Nations Economic and Social Commission for Asia and the Pacific characterize good governance indicators as follows: participation, rule of law, transparency, responsiveness, consensus oriented, equity and inclusiveness, effectiveness and efficiency and accountability. ${ }^{24}$ While principles, such as accountability, efficiency, transparency or the rule of law belong to the administrative core, respect for human rights, participation and democratization belong to the political core. While some focus on the administrative core to the proper functioning of the state administration and the regulative framework, ${ }^{25}$ other authors highlight the element of democracy, as a key variable for good governance. ${ }^{26}$ Despite numerous definitions by various organizations, the United Nations Economic and Social Commission for Asia and the Pacific present the most applicable framework for reliable and appropriate assessment of governance, because combine political, social and economic cores. The following section focus on governance in Syria.

\section{Poor Governance in Syria}

This section investigates good governance in Syria. Based on United Nations Economic and Social Commission for Asia and the Pacific, good governance has 7 major characteristics which will be applied on Syria to examine governance situation.

23 Kardos Mihaela, "The Reflection of Good Governance in Sustainable Development Strategies," Procedia-Social and Behavioral Sciences 58 (2012): 1166-73.

24 Sheng Yap Kioe, "What Is Good Governance," United Nations Economic and Social Commission for Asia and the Pacific, (2008), 1.

25 Kardos, "The Reflection of Good," 1172.

26 Neumayer Eric, The Pattern of Aid Giving: The Impact of Good Governance on Development Assistance, (Routledge, 2005), 5. 


\subsection{Participation}

Participation is one of the 7 major characteristics of good governance. Although participation is essential to good governance, ${ }^{27}$ representative democracy and holding election as such do not make a country democratic. The most obvious evidence is that in single-party governments, more than $99 \%$ of the votes are cast in favor of the ruling party. ${ }^{28}$ Participation needs to be informed and organized which means freedom of association and expression and an organized civil society. ${ }^{29}$ Table one and two show voter turnout in parliamentary and presidential elections in Syria.

\section{Table 1. Voter turnout in Parliamentary Elections in Syrian Arab Republic $^{30}$}

\begin{tabular}{|c|c|c|c|c|c|c|c|}
\hline Year & $\begin{array}{c}\text { Voter } \\
\text { Turnout }\end{array}$ & $\begin{array}{c}\text { Total } \\
\text { vote }\end{array}$ & Registration & $\begin{array}{c}\text { VAP } \\
\text { Turnout }\end{array}$ & $\begin{array}{c}\text { Voting age } \\
\text { population }\end{array}$ & Population & $\begin{array}{c}\text { Compulsor } \\
\text { y voting }\end{array}$ \\
\hline 2012 & $51.26 \%$ & $2,658,834$ & $5,186,957$ & $20.28 \%$ & $13,113,495$ & $22,530,746$ & No \\
\hline 2007 & $56.00 \%$ & $4,371,357$ & $7,805,994$ & $41.52 \%$ & $10,527,648$ & $19,314,747$ & No \\
\hline 2003 & $63.45 \%$ & $4,556,475$ & $7,181,206$ & $50.05 \%$ & $9,104,574$ & $17,874,577$ & No \\
\hline 1998 & $82.22 \%$ & $5,501,940$ & $6,691,323$ & $79.04 \%$ & $6,960,764$ & $15,294,662$ & No \\
\hline 1994 & $61.17 \%$ & $3,693,656$ & $6,037,885$ & $58.00 \%$ & $6,368,240$ & $13,844,000$ & No \\
\hline
\end{tabular}

Table 2. Voter turnout in Presidential Elections in Syrian Arab Republic in $2014^{31}$

\begin{tabular}{|c|c|c|c|c|c|c|c|}
\hline $\begin{array}{c}\text { Voter } \\
\text { Turnout }\end{array}$ & Total vote & $\begin{array}{c}\text { Regi- } \\
\text { stration }\end{array}$ & $\begin{array}{c}\text { VAP } \\
\text { Turnout }\end{array}$ & $\begin{array}{c}\text { Voting age } \\
\text { population }\end{array}$ & Population & $\begin{array}{c}\text { Invalid } \\
\text { votes }\end{array}$ & $\begin{array}{c}\text { Compulsory } \\
\text { voting }\end{array}$ \\
\hline $73.42 \%$ & $11,634,412$ & $15,845,575$ & $112.23 \%$ & $10,366,191$ & $17,951,639$ & $3.80 \%$ & No \\
\hline
\end{tabular}

27 Sheng, What Is Good Governance, 1.

28 Rose Richard, International Encyclopedia of Elections. Cq Pr, 2000.

29 Sheng, What Is Good Governance, 2.

30 IDEA. "Voter Turnout Data for Syrian Arab Republic," International Institute for Democracy and Electoral Assistance (International IDEA), 2011.

31 IDEA. "Voter Turnout Data for Syrian Arab Republic," International Institute for Democracy and Electoral Assistance (International IDEA), 2015. 


\subsection{Rule of Law}

Good governance requires just legal frameworks and also complete protection of human rights, and in particular minorities' rights. ${ }^{32}$ The rule of law and separation of powers shows how power is exercised, disputes are settled and to what extent government is in concord with the legal system. Regarding that the rule of law helps to protect the rights of individuals, a country with a better functioning legal system is expected to resolve grievances, peacefully. ${ }^{33}$ Because a country with the rule of law tends to accept non-violent mechanisms to settle conflicts, it supports peaceful responses to civil tensions. Since the rule of law requires the guarantee of individuals' rights, it is also important to recognize its strong links with the acceptance of the rights of others. Hence, the rule of law requires both formal institutions and a culture supporting them. ${ }^{34}$ Table three shows the status of rule of law in Syria, from 1996 to 2014.

Table 3. Rule of law in Syrian Arab Republic, 1996-2014 ${ }^{35}$

\begin{tabular}{|l|r|r|r|r|r|r|r|r|r|r|}
\hline Year & $\mathbf{1 9 9 6}$ & $\mathbf{1 9 9 8}$ & $\mathbf{2 0 0 0}$ & $\mathbf{2 0 0 2}$ & $\mathbf{2 0 0 4}$ & $\mathbf{2 0 0 6}$ & $\mathbf{2 0 0 8}$ & $\mathbf{2 0 1 0}$ & $\mathbf{2 0 1 2}$ & $\mathbf{2 0 1 4}$ \\
\hline Rule of Law: Estimate & -0.38 & -0.35 & -0.37 & -0.42 & -0.37 & -0.86 & -0.60 & -0.50 & -1.10 & -1.34 \\
\hline $\begin{array}{l}\text { Rule of Law: Percentile } \\
\text { Rank }^{36}\end{array}$ & 38.3 & 39.7 & 40.2 & 38.8 & 42.1 & 22.5 & 34.6 & 36.5 & 14.2 & 6.7 \\
\hline $\begin{array}{l}\text { Rule of Law: Percentile } \\
\text { Rank, Lower Bound of 90\% } \\
\text { Confidence Interval }\end{array}$ & 27.6 & 28.1 & 31.4 & 28.6 & 31.0 & 11.4 & 21.1 & 27.4 & 5.7 & 1.9 \\
\hline $\begin{array}{l}\text { Rule of Law: Percentile } \\
\text { Rank, Upper Bound of 90\% } \\
\text { Confidence Interval }\end{array}$ & 49.5 & 52.4 & 50.0 & 49.0 & 50.5 & 34.8 & 44.0 & 47.6 & 23.1 & 14.4 \\
\hline Rule of Law: Standard Error & 0.21 & 0.22 & 0.18 & 0.20 & 0.19 & 0.17 & 0.15 & 0.15 & 0.16 & 0.19 \\
\hline
\end{tabular}

32 Sheng, What Is Good Governance, 2.

33 IEP. "Global Terrrosim Index Report," The Institute for Economics and Peace, 2014b.

34 Mani Rama, "Conflict Resolution, Justice and the Law: Rebuilding the Rule of Law in the Aftermath of Complex Political Emergencies," International Peacekeeping 5, no. 3 (1998): 1-25.

35 World Bank. "Worldwide Governance Indicators (WGI), Country Data Report for Syrian Arab Republic," 1996-2014, 2014b. http://info.worldbank.org/governance/wgi/ index.aspx?fileName $=$ c209.pdf.

360 corresponds to lowest rank and 100 to highest rank. 


\subsection{Transparency}

Transparency means that decisions are taken and enforced in accordance with rules and regulations. ${ }^{37}$ Accurate and well-distributed information provide transparency of government decisions. It also means that enough information in easily understandable forms is provided. Lack of transparency means corruption. As IEP findings shows, there is a correlation between low level of corruption and peace, ${ }^{38}$ in other words the high level of corruption, the less level of peace. Table four shows the level of corruption in Syria.

Table 4. The level of corruption in Syria ${ }^{39}$

\begin{tabular}{|l|l|l|l|}
\hline \multicolumn{2}{|l|}{ Corruption Perception Index (2014) } & \multicolumn{2}{l|}{$\begin{array}{l}\text { Control of Corruption } \\
(2010)\end{array}$} \\
\hline Rank & Score & Percentile rank & Score \\
\hline $159 / 175$ & $20 /{ }^{100}$ & $15 \%$ & -1.0539 \\
\hline
\end{tabular}

\subsection{Responsiveness and Accountability}

Voice and accountability bring the responsiveness of politicians. IEP ${ }^{40}$ analysis supported this idea that countries which are more peaceful tend to also have a greater capacity for citizens to interact with government and hold it to account. Accountability is required to good governance. Not only governmental institutions but also the private sector and civil society organizations must be accountable to the public and to their institutional stakeholders. Accountability cannot be enforced without transparency and the rule of law. ${ }^{41}$ Accountability is hard to achieve without adequate access to information. Accountability can be classified in four categories as following public, financial, horizontal and vertical. Informal checks on these relationships are reinforced by the civil society. Table five shows voice and accountability for Syria.

37 Sheng, What Is Good Governance, 3.

38 IEP, 2014b.

39 Transparency International. “Corruption Perceptions Index 2014.” http://files.transparency. org/content/download/1856/12434/file/2014_CPIBrochure_EN.pdf.

40 IEP, 2014b.

41 Sheng, What Is Good Governance, 4. 
Table 5. Government accountability in Syria, 1996- 2014

\begin{tabular}{|l|r|r|r|r|r|r|r|r|r|r|}
\hline Year & 1996 & 1998 & 2000 & 2002 & 2004 & 2006 & 2008 & 2010 & 2012 & 2014 \\
\hline $\begin{array}{l}\text { Voice and Accountability: } \\
\text { Estimate }\end{array}$ & -1.33 & -1.48 & -1.55 & -1.59 & -1.52 & -1.70 & -1.67 & -1.64 & -1.80 & -1.80 \\
\hline $\begin{array}{l}\text { Voice and Accountability: } \\
\text { Percentile Rank }\end{array}$ & 10.6 & 8.2 & 6.7 & 5.8 & 7.2 & 5.8 & 4.3 & 4.7 & 3.3 & 3.0 \\
\hline $\begin{array}{l}\text { Voice and Accountability: } \\
\text { Percentile Rank, Lower } \\
\text { Bound of 90\% Confidence } \\
\text { Interval }\end{array}$ & 4.3 & 2.9 & 1.9 & 1.9 & 3.8 & 2.9 & 3.8 & 3.8 & 2.4 & 2.0 \\
\hline $\begin{array}{l}\text { Voice and Accountability: } \\
\text { Percentile Rank, Upper } \\
\text { Bound of 90\% Confidence } \\
\text { Interval }\end{array}$ & 19.6 & 16.3 & 13.9 & 12.4 & 13.4 & 8.1 & 8.6 & 9.0 & 4.7 & 5.4 \\
\hline $\begin{array}{l}\text { Voice and Accountability: } \\
\text { Standard Error }\end{array}$ & 0.22 & 0.23 & 0.23 & 0.17 & 0.15 & 0.12 & 0.12 & 0.12 & 0.12 & 0.14 \\
\hline
\end{tabular}

\subsection{Consensus Oriented}

Good governance requires inclusion of various interest groups in the society to reach a broad consensus which is a peaceful way to support all of the stakeholders' interests. This is in a tight connection with broad and long-term perspective on the requirements of sustainable development and also strategies to achieve such development. ${ }^{43}$ Consensus decision-making requires to identify and address concerns, to generate new alternatives, to combine elements of multiple alternatives and to check that people understand a proposal or an argument that empowers minorities. Table six shows Syria's rank in democracy and also their score in civil liberties. Also, table seven shows inclusions of minorities in Syria.

Table 6. Civil liberties and democracy rank in Syria ${ }^{44,45}$

\begin{tabular}{|l|c|c|c|}
\hline Country & 2015 Civil Liberties Score & 2014 Civil Liberties Score & Democracy Rank 2015 \\
\hline Syria & 7 & 7 & 144 \\
\hline
\end{tabular}

42 World Bank, 2014b.

43 Graham John, Bruce Amos, and Tim Plumptre. "Principles for Good Governance in the 21st Century." Policy brief 15 (2003): 1-6.

44 World Audit Civil Liberties. "Civil Liberties.” 2015, Accessed January 6. http://www. worldaudit.org/civillibs.htm.

451 representing the most free and 7 the least free. 
Table 7. Inclusion of minorities in Syria in $2010^{46}$

\begin{tabular}{|c|c|}
\hline Inclusion & se_inclusion \\
\hline 0.3986015 & 0.0065119 \\
\hline
\end{tabular}

\subsection{Equity and Inclusiveness}

A society's well-being requires that all members feel the sense of being included and do not feel excluded from the mainstream of society. This requires all groups, and in particular the most vulnerable, have opportunities to improve or maintain their well-being. ${ }^{47}$ Inequality-adjusted Human Development Index and also freedom status show equity and inclusiveness in different countries. Tables eight shows Inequality-adjusted Human Development Index, and table nine shows freedom status in Syria.

Table 8. Inequality-adjusted Human Development Index in $2015^{48}$

\begin{tabular}{|c|c|c|c|c|c|c|c|c|}
\hline \multicolumn{2}{|c|}{$\begin{array}{c}\text { Inequality-adjusted } \\
\text { HDI (IHDI) }\end{array}$} & $\begin{array}{c}\text { Coefficient } \\
\text { of human } \\
\text { inequality }\end{array}$ & $\begin{array}{c}\text { Inequality } \\
\text { in life } \\
\text { expectancy }\end{array}$ & $\begin{array}{c}\text { Inequality- } \\
\text { adjusted life } \\
\text { expectancy } \\
\text { index }\end{array}$ & $\begin{array}{c}\text { Inequality } \\
\text { in } \\
\text { education }\end{array}$ & $\begin{array}{c}\text { Inequality- } \\
\text { adjusted } \\
\text { education } \\
\text { index }\end{array}$ & $\begin{array}{c}\text { Inequality } \\
\text { in income }\end{array}$ & $\begin{array}{c}\text { Inequality- } \\
\text { adjusted } \\
\text { income } \\
\text { index }\end{array}$ \\
\hline Value & $\begin{array}{c}\text { Overall } \\
\text { loss (\%) }\end{array}$ & & $(\%)$ & Value & $(\%)$ & Value & $(\%)$ & Value \\
\hline 0.419 & 21.7 & 21.4 & 14.5 & 0.653 & 31.5 & 0.286 & 18.3 & 0.394 \\
\hline
\end{tabular}

Table 9. Freedom status in Syria ${ }^{49,50}$

\begin{tabular}{|c|c|c|c|c|c|c|c|c|c|c|c|c|c|c|c|c|c|c|c|c|c|}
\hline 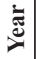 & \multicolumn{3}{|c|}{1990} & \multicolumn{3}{|c|}{2000} & \multicolumn{3}{|c|}{2004} & \multicolumn{3}{|c|}{2009} & \multicolumn{3}{|c|}{2010} & \multicolumn{3}{|c|}{2012} & \multicolumn{3}{|c|}{2014} \\
\hline & $\mathrm{PR}$ & $\mathrm{CL}$ & Status & PR & CL & Status & PR & CL & Status & PR & CL & Status & $\mathrm{PR}$ & CL & Status & & $\mathrm{CL}$ & Status & PR & & Status \\
\hline 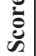 & 7 & 7 & $\mathrm{NF}$ & 7 & 7 & $\mathrm{NF}$ & 7 & 7 & NF & 7 & 6 & $\mathrm{Nl}$ & 7 & 6 & $\mathrm{NF}$ & 7 & 7 & $\mathrm{NF}$ & 7 & 7 & NF \\
\hline
\end{tabular}

46 ISS. "Indices of Social Development, Inclusion of Minorities." 2010. http://www.indsocdev. org/data-access.html.

47 Sheng, What Is Good Governance, 4.

48 UNDP. "Inequality-Adjusted Human Development Index" 2015, www.Hdr.undp.org/en/ composite/IHDI\#b.

$49 \mathrm{PR}$ and CL stand for political rights and civil liberties, respectively; 1 represents the most free and 7 the least free rating.

50 Freedom House. "Freedom in the World Comparative and Historical Data, Individual Country Ratings and Status, Fiw 1973-2015.” https://freedomhouse.org/report-types/ freedom-world. 


\subsection{Effectiveness and Efficiency}

Good governance means that processes and institutions not only meet the needs of society, completely, but also make use of resources, optimally. Also, efficiency requires the sustainable use of natural resources and the protection of the environment. ${ }^{51}$ It also promotes efficient public delivery systems. One aspect of poor service delivery is corruption which can be alleviated by competitive salaries and motivating staff through incentives. Table ten shows government effectiveness in Syria.

Table 10. Government Effectiveness in Syria, 1996- 2014 ${ }^{52}$

\begin{tabular}{|l|r|r|r|r|r|r|r|}
\hline Year & $\mathbf{1 9 9 6}$ & $\mathbf{2 0 0 0}$ & $\mathbf{2 0 0 4}$ & $\mathbf{2 0 0 8}$ & $\mathbf{2 0 1 0}$ & $\mathbf{2 0 1 2}$ & $\mathbf{2 0 1 4}$ \\
\hline $\begin{array}{l}\text { Government Effectiveness: } \\
\text { Estimate }\end{array}$ & -0.64 & -0.99 & -1.05 & -0.62 & -0.60 & -1.22 & -1.44 \\
\hline $\begin{array}{l}\text { Government Effectiveness: } \\
\text { Percentile Rank }\end{array}$ & 28.3 & 12.7 & 11.2 & 31.1 & 32.5 & 10.0 & 6.7 \\
\hline $\begin{array}{l}\text { Government Effectiveness: } \\
\text { Percentile Rank, Lower Bound of } \\
\text { 90\% Confidence Interval }\end{array}$ & 14.1 & 5.3 & 6.3 & 16.4 & 18.6 & 3.3 & 1.9 \\
\hline $\begin{array}{l}\text { Government Effectiveness: } \\
\text { Percentile Rank, Upper Bound of } \\
\text { 90\% Confidence Interval }\end{array}$ & 47.1 & 30.6 & 26.2 & 45.9 & 44.8 & 21.4 & 16.3 \\
\hline $\begin{array}{l}\text { Government Effectiveness: } \\
\text { Standard Error }\end{array}$ & 0.25 & 0.24 & 0.22 & 0.20 & 0.20 & 0.22 & 0.24 \\
\hline
\end{tabular}

\section{Discussion}

Syria has been long ruled by one family that enriches itself at the expense of the great majority of its people. When Bashar took power, the regime became more an Alawite and family affair. One brother, Maher, heads the Presidential Guard; a cousin on his mother's side, Adnan Makhlouf, commands the Republican Guard; and two other cousins, Adnan and Muhammad al-Assad, are leaders of the Struggle Companies. Almost the only non-Alawite among them was Manaf Tlas, son of perennial defense minister and one of Hafiz's oldest friends, Mustafa Tlas. ${ }^{54}$

51 Sheng, What Is Good Governance, 4.

52 World Bank, 2014b.

53 Ranging from approximately-2.5 to 2.5.-2.5 represent the most ineffective and 2.5 represent the most effective.

54 Barry Rubin, The Truth About Syria, (Macmillan, 2007), 3. 
What can be meant participation (factor 1) in such a state? This is a fact which that shows representative democracy cannot necessarily make a country democratic, and sheer attention to voter turnout can be misleading. Voter turnout have always been above 65 per cent and 70 per cent in Syrian parliamentary and presidential elections, respectively (see table 2). But, when voters are forced to elect the candidates from a pack which Bashar characterizes, when there is no civil society which support and protect democracy and control the state behavior, when there is no independent supervisory committee to monitor elections, and when there is no freedom (of speech, press etc.), elections cannot mean something more than demagoguery, and political show. Syria is a republic which is ruled by one family, and real democracy and participation threaten the ruling family.

The rule of law (factor 2) corresponds to civil harmony/tension. Because a country with the rule of law tends to accept non-violent mechanisms to settle conflicts, it supports peaceful responses to civil tensions. President in Syria Ba'th System is the source of law making. President can announce state of emergency ${ }^{55}$ (principle 101 of Syria Constitution 1973), and make low (principle 111 of Syria Constitution 1973). He is also the head of Supreme Judicial Council (principle 132 of Syria Constitution 1973) which violate judicial independence.

Situation of rule of law in Syria shows a downtrend from 1996 to 2014 (see table 3). Syria lacks such a mechanism. What began as a peaceful civil uprising in 2011 has devolved into a complex, protracted civil war. Assad's system neither provides just legal frameworks and full protection of human rights, nor a culture supporting rule of law.

In such a system, disputes are intended to be converted to complicated civil wars, and the ruling family is not intended to settle the conflict peacefully. Syrian President Bashar al-Assad has consistently called the opposition forces as terrorists. Assad's system response to the tension was aerial bombing as a counterinsurgency tactic which in view point of some scholars drives civilian populations to support the insurgents. ${ }^{56}$ Moreover, such

55 Syria's government has passed a bill lifting the country's emergency law, just hours after security forces fired on protesters in 2011. In the state of emergency, the president has the power of making law with this excuse that national security is under threat.

56 Kocher Matthew Adam, Thomas B Pepinsky, and Stathis N Kalyvas. "Aerial Bombing and Counterinsurgency in the Vietnam War," American Journal of Political Science 55, no. 2 (2011): 201-18. 
tactics also have increased the number of attacks from insurgents. The result of this process has been lasting civil war in Syria.

Based on the IEP findings, there is a correlation between low level of corruption (factor 3 ) and peace, ${ }^{57}$ in other words the high level of corruption, the less level of peace. In IEP's 2014 Global Terrorism Index ${ }^{58}$ report it was found that the ten nations most impacted by terrorism were also more corrupt when compared to the global average. Transparency International $(\mathrm{TI})^{59}$ reported that Syria is ranked in corruption perception index 159 out of 175 states survived by TI. In terms of control of corruption Syria's score is about -1.0539 , and it is ranked among highly corrupted states.

But how Assad's system has responded to the problem? As Rubin ${ }^{60}$ put it "Bashar's strategy was to enhance his credentials as a militant Arab nationalist, a fighter against Israel, defender of Islam, friend of revolutionaries, and sworn foe of America." This strategy is called "resistance." "Resistance" is to battle against something, not to have any positive program. The word means a reactionary effort to maintain an undesirable status quo. In March 2001, Syrian Vice-President Abd Halim Khaddam answered to the question that "why the regime did not do more to solve the problems of corruption, and incompetence", his answer was that the Arab-Israeli conflict do not permit changes and reforms. Corruption actually has become an integral part of the system. Licenses to commit corruption are given to regime supporters. In Assad's system corruption is not a disease but is one of the many antibodies the system uses to survive.

Voice and accountability (factor 4) describes how strongly the public is able to influence and participate in the decision-making processes of government and the wider society. As it is emphasized Syria is ruled by one family, and participation in decision making process is only possible for persons who are from ruling Alawite family. The World Bank ${ }^{61}$ data for Syria in term of voice and accountability index during 1996 to 2014 show

57 IEP, 2014b.

58 IEP, 2014a.

59 Transparency International. “Corruption Perceptions Index 2014.” http://files.transparency. org/content/download/1856/12434/file/2014_CPIBrochure_EN.pdf.

60 Rubin, The Truth About Syria, 16.

61 World Bank, 2014b. 
that the average value for Syria is -1.65 points with a minimum of -1.80 points in 2014 and a maximum of -1.33 points in 1996. Syria is ranked 187 out of 193 states.

Assad's system ascribes any deficiency to the enemy. The following statement reveals lack of voice and accountability in Assad's system: 'and your problem, the reason that life is not better, is not due to your government's incompetence, greed and oppression. Rather, your enemy is the imperialists and Zionists who are holding you back and want to destroy everything you have and enslave you. Therefore, to fight for your rights you must unite behind -not against- your dictator. ${ }^{3}$

Good governance requires mediation of various interest groups in the society to reach a broad consensus (factor 5). Syria is a fragile ethno-religious entity, and the country's population is divided among Sunni Arabs, Christians, Alawites, Druze, and various ethnic minorities, primarily Turkmens and Kurds. ${ }^{63}$ The Alawite Assad family has based its power on the solid loyalty of its religious bloc in a fragile alliance with Christians, Druze, and sometimes, on one or more other smaller ethnic groups. Alawite ruling family needed a doctrine which would justify not only its hold on power in Syria but also that state's expansion to colonize its neighbors. This strategy was inspiring a common fear.

For nation-building to occur, the ruling political elites of the state must represent a core group that is well defined and has a clear criterion of inclusion. Consensus making and inclusion of different interest groups is a prerequisite for nation-building. Exclusion of different interest groups threaten peace and may bring instability. Syrian Constitution (passed in 1973) do not have this potential of inclusion of different interest groups. Principle one of the Syrian Constitution introduces Syria as an Arab state and ignore non-Arab nation living in Syria. Also, principle 4 characterizes Arabic as a formal language and do not recognize other languages. A prominent feature of the 2011-12 rebellion is a largely Sunni Arab bid to overthrow that "coalition of minorities" regime. In fact, civil war in Syria

62 Rubin, The Truth About Syria, 26.

63 Carpenter Ted Galen. "Tangled Web: The Syrian Civil War and Its Implications," Mediterranean Quarterly 24, no. 1 (2013): 1-11. 
has emerged along an array of different cleavages including a repressed majority versus a dominant minority divide, with notable center-periphery tensions, ${ }^{64,65}$ and a secular-versus-religious/jihadist cleavage, which overlaps partly but not fully with the ideological cleavages.

Beside of inclusiveness, equity (factor 6) is the other prerequisite for good governance. Inequality-adjusted Human Development Index shows the level of equity and inclusiveness. Based on the UNDP, ${ }^{66}$ Syria is ranked in 149 in terms of Inequality-adjusted Human Development Index. As the data show Assad's system could not establish equity among different interest groups. The other factor which is in close relation with equity is freedom status. Equity without freedom cannot be established. Freedom House $^{67}$ findings in terms of freedom status in Syria during 1990 to 2014 show that it is among least Free states and is NOT a free state. Assad's system has seen any request for freedom and equity as poison. Bashar defines freedom as having no "controls so that [foreign enemies] could blackmail any regime from the inside' and he defines economic reform, 'They want us to open our markets' in exchange for very little in return, and also, he defines cultural reforms 'the West wants Syrians to become a copy of them. ${ }^{68}$

The last factor in good governance is government effectiveness (factor 7). It means that government make the optimal use of resources in order to meet the needs of public. The World Bank ${ }^{69}$ data for Syria in term of effectiveness and efficiency index during 1996 to 2014 show that the average value for Syria is -0.99 points with a minimum of -1.44 points in 2014 and a maximum of -0.60 points in 2010. But how Assad's system justifies the government ineffectiveness is so interesting. 'Your problem, the reason that life is not better, is not due to your government's incompetence, greed and oppression. Rather, your enemy is the imperialists and Zionists who are holding you back and want to destroy everything you have and enslave

\footnotetext{
64 Fearon, 2004.

65 Fearon James D, and David D Laitin. "Sons of the Soil, Migrants, and Civil War," World Development 39, no. 2 (2011): 199-211.

66 UNDP, 2015.

67 Freedom House, 2016.

68 Rubin, The Truth About Syria, 119.

69 World Bank, 2014b.
} 
you. ${ }^{70}$ Judge us not by our economic performance or delivery of services, he says in effect, but by our steadfastness and intransigence. ${ }^{71}$ Blaming others for one's troubles and believing that removal of this heavy external hand will allow quick and easy progress has been Assad's system strategy to keep holding power.

\section{Conclusion}

This article began with the observation that poor governance is an important concept in search of civil war cause. To that end, this article makes two main contributions. First, it demonstrates that the state is the main but not the sole responsible for peace/war. Second, it makes a difference between causes and factors in civil war investigation.

Good governance indicators can guide us to find civil war causes. Looking at these indicators show: lack of free and fair elections, low level of rule of law, high level of corruption, lack of voice and accountability, exclusion of different interest groups, inequity and government ineffectiveness in Syria during the covered years. These indicators would be more meaningful when are investigated considering the factors like the nature of regional and international systems.

Syria which has been long ruled by one family who enriches itself at the expense of the great majority of its people. Assad's system believes that a utopia could be built in the country by removing all of diversities including ideology, ethnic, religious and political diversities. Bashar insists that reforms are poison for all Syrians. Foreign enemies are a discourse to justify its domestic deficiencies and its rule. Like his father Bashar is virtually indifferent to economic or social issues. He is not interested in talking about the need for education, better health, equality for women, or any other development issue. He believes that the solution of shortcomings is not reforms but resistance, not social change but struggle. In this situation, Arab Spring acted as a spark and civil war in Syria were started. Bashar alAssad has consistently called the opposition forces as terrorists. Regional and international powers intervention have caused the war to become more

70 Rubin, The Truth About Syria, 26.

71 Rubin, The Truth About Syria, 193. 
complicated. The result is 6- year war, about 500 thousand causalities and displacement of about 8 million.

The civil war in Syria will not be ended until a democratic state is established. Creation of a global alliance to fight against terrorism provided that the different forces fighting against terrorism in Syria are united under the supervisory of the UN. Holding a free and fair elections under supervisory of the UN supervision committee can be the second step. The third step would be withdrawing of regional and international states forces from Syria except for UN peacekeeping forces. Prosecution of war crimes perpetrators would be last but fair step.

\section{Bibliography}

Albornoz, Facundo and Esther Hauk. "Civil War and U.S. Foreign Influence.” Journal of Development Economics 110 (2014): 64-78.

Armed Conflict Report. ProjectPloughsharesploughshares.ca/wp-content/../2014ARMED-CONFLICT-REPORT.pdf.

Blattman, Christopher and Edward Miguel. "Civil War." Journal of Economic Literature (2010): 3-57.

Carpenter, Ted Galen. "Tangled Web: The Syrian Civil War and Its Implications.” Mediterranean Quarterly 24, no. 1 (2013): 1-11.

Collier, Paul. Breaking the Conflict Trap: Civil War and Development Policy. World Bank Publications, 2003.

Collier, Paul. Understanding Civil War: Africa. Vol. 1: World Bank Publications, 2005.

Connor, Walker. Ethnonationalism. Wiley Online Library, 1994.

Cortright, David. Peace: A History of Movements and Ideas. Cambridge University Press, 2008.

Djankov, Simeon, and Marta Reynal-Querol. "Poverty and Civil War: Revisiting the Evidence." The Review of Economics and Statistics 92, no. 4 (2010): 1035-41.

Evans, Idris, Jessica Lane, Megan Turner and Jessica Pealer. "A Conceptual Model of Peace Building and Democracy Building: Integrating the Fields." 2013. 
Fearon, James D and David D Laitin. "Sons of the Soil, Migrants, and Civil War." World Development 39, no. 2 (2011): 199-211.

Fearon, James D. "Ethnic Mobilization and Ethnic Violence." The Oxford Handbook of Political Economy (2006): 852-68.

Fearon, James D. "Why Do Some Civil Wars Last So Much Longer Than Others?." Journal of peace research 41, no. 3 (2004): 275-301.

Gellner, Ernest, and John Breuilly. Nations and Nationalism. Cornell University Press, 2008.

Graham, John, Bruce Amos, and Tim Plumptre. "Principles for Good Governance in the 21st Century." Policy brief 15 (2003): 1-6.

Haavelmo TT, A Study in the Theory of Economic Evolution. (Netherlands: North Holland Publishing Company, 1954).

Harbom, Lotta, Stina Högbladh and Peter Wallensteen. "Armed Conflict and Peace Agreements." Journal of Peace Research 43, no. 5 (2006): 61731.

Heywood, Andrew. Global Politics. Palgrave Macmillan, 2011.

Horowitz, Donald L. Ethnic Groups in Conflict. Univ of California Press, 1985.

House, Freedom. "Freedom in the World Comparative and Historical Data, Individual Country Ratings and Status, Fiw 1973-2015." https://freedomhouse.org/report-types/freedom-world.

IDEA. "Voter Turnout Data for Syrian Arab Republic." International Institute for Democracy and Electoral Assistance (International IDEA), 2011.

IDEA. "Voter Turnout Data for Syrian Arab Republic." International Institute for Democracy and Electoral Assistance (International IDEA), 2015.

IEP. "Global Terrrosim Index Report.” The Institute for Economics and Peace, economicsandpeace.org/wp-content/uploads/.../Terrorism-Index-Report.pdf. IEP. "Pillars of Peace." 2014. The Institute for Economics and Peace.

ISS. "Indices of Social Development, Inclusion of Minorities." http:// www.indsocdev.org/data-access.html. 
Kardos, Mihaela. "The Reflection of Good Governance in Sustainable Development Strategies." Procedia-Social and Behavioral Sciences 58 (2012): 1166-73.

Kinsella, David and D Rousseau. "Democracy and Conflict Resolution." Handbook on Conflict Resolution (2009): 475-92.

Klem, M and G Frerks. "How Local Governments Contribute to PeaceBuilding." Musch et al.(2006) City Diplomacy. The Role of Local Governments in Conflict Prevention, Peace-building, Post-Conflict Reconstruction. The Hague: VNG International (2008): 47-74.

Kocher, Matthew Adam, Thomas B Pepinsky, and Stathis N Kalyvas. "Aerial Bombing and Counterinsurgency in the Vietnam War." American Journal of Political Science 55, no. 2 (2011): 201-18.

Mani, Rama. "Conflict Resolution, Justice and the Law: Rebuilding the Rule of Law in the Aftermath of Complex Political Emergencies." International Peacekeeping 5, no. 3 (1998): 1-25.

Neumayer, Eric. The Pattern of Aid Giving: The Impact of Good Governance on Development Assistance. Routledge, 2005.

Rose, Richard. International Encyclopedia of Elections. Cq Pr, 2000.

Rubin, Barry. The Truth About Syria. Macmillan, 2007.

Sambanis, Nicholas. "Using Case Studies to Refine and Expand the Theory of Civil War." Understanding civil war 1 (2005): 303-34.

Sheng, Yap Kioe. "What Is Good Governance." United Nations Economic and Social Commission for Asia and the Pacific. (2008).

Smith, Rupert. The Utility of Force: The Art of War in the Modern World. Vintage Books USA, 2008.

Transparency International. "Corruption Perceptions Index 2014." http:// files.transparency.org/content/download/1856/12434/file/2014_CPIBrochure_EN.pdf.

UNDP. “Inequality-Adjusted Human Development Index.” www.Hdr. undp.org/en/composite/IHDI\#b.

World Audit Civil Liberties. "Civil Liberties." http://www.worldaudit.org/ civillibs.htm. 
World Bank. "Worldwide Governance Indicators." 2014a. http://databank. worldbank.org/data/reports.aspx?Report_Name=WGI-Table\&Id=ceea4d8b.

World Bank. "Worldwide Governance Indicators (Wgi), Country Data Report for Syrian Arab Republic, 1996-2014." 2014b. http://info.worldbank. org/governance/wgi/index.aspx?fileName=c209.pdf. 